\title{
二重車輪軸の自由摇動機構を利用する 直管内ロボット姿勢モニタ
}

大 谷智 康*1 吉 田 亮*2 岡 田 徳 次*1

\author{
Orientation Monitoring of the Robot in a Straight Pipe by Utilizing \\ Free Rocking Mechanism of Wheel Shaft around Robot Stem
}

\author{
Tomoyasu Ohya*1, Ryo Yoshida ${ }^{* 2}$ and Tokuji Okada*1
}

\begin{abstract}
This paper describes a method for monitoring orientation of wheel-type or crawler-type robots in a pipe. Orientation of the robot in the pipe is important for controlling locomotion of the robots stably with dead reckoning. Basically, axes connecting left and right wheels are fixed to vehicle body. However our axes are possible to rock around the vehicle body, since the axes are freely connected to the main stem of the vehicle body at front and rear. According as the robot moves in the pipe, rocking angles of the axes are changed, and these angles are collected to know the configuration of the vehicle body. At first the structures of the robot and the free rocking mechanism are explained. Then the method for calculating the orientation utilizing rocking angles is described. Also, the optimum design of the free rocking mechanism is discussed. Finally the prototype of the robot having the monitoring function in the pipe is designed for verifying the monitoring method.
\end{abstract}

Key Words: Robot in Pipe, Orientation Monitoring of the Robot, Rocking Mechanism, Dead Reckoning

\section{1.はじめに}

一般に移動ロボットの三次元空間姿勢は，1）積分型ジャイロ スコープ，2）傾斜計，3）外界との接触をもつ相対角度センサ などにより測定される１1）は角速度を検出しこれを積分するた め, ジャイロスコープの出力誤差の累積を避けられないが小型 化・軽量化できる効果により広く利用される. 青野らは起伏地で のデッドレコニングに光ファイバジャイロを用いている [1]．2） は重力加速度方向からのずれを傾斜として検出するため，ロボッ トの運動による加速度も含めて検出するが，1）と異なり初期設 定を必要としない，傾斜角の範囲を全立体角に拡張する様々な 全作用力方向センサも提案されている [2].これらは低速移動 の管内ロボットのための傾斜計として使用できる．3）は主に多 足歩行ロボットにおいて, 接地面を倣う足部の関節角を検出し, 走行面に対する相対的な姿勢情報を得る手法である. Zheng ら は斜面に適応する静的歩行の実現に関節角センサの情報を用い ている [3]. 本稿で述べる手法は 3) に属し，文献 [4] で提案さ れた自由摇動機構を用いて管壁面を倣わせることでロボット構 造の変形状況を知り，管壁に対する相対的な姿勢を算出する.

原稿受付 2000 年 5 月 12 日

$* 1$ 新潟大学工学部

*2アルパイン (株)

${ }^{* 1}$ Faculty of Engineering Niigata University

${ }^{* 2}$ Alpine Electronics,Inc.
本来「姿勢」という言葉は「頭部，体幹，四肢の相対的位置関 係」または「それを保つようす」を意味し，英語の「posture」 にあたる。また工学における「姿勢」は必ずしも生体と結びつ くとは限らない. 特にロボット工学では「対象に固定する座標 系間の相対的な傾き」として用いられることが多い.これは英 語の「orientation」に該当する。ただし，転倒の危険性を有す る 2 足歩行ロボットや曲面走行ロボットの場合, 重力加速度方 向を基準とする姿勢が重要であり，これを単に「姿勢」と呼ぶ こともある。管内ロボットも，こうした姿勢情報は必要である が，本稿で扱うロボットは車輪を管壁面に常に押しつけること により自立する機構を有するため, むしろ走行環境である管壁 に対するロボットの相対的な姿勢情報を必要とする。したがっ て, 本稿では「姿勢」を「orientation」と解釈し, 管壁上の特 定な位置を基準とする局所座標系において，ロボットの各部要 素に固定される座標系が相対的に傾く角度を姿勢と呼ぶことに する.

平面機構を有する車輪型やクローラ型管内ロボットにとって, 自身の姿勢は転倒の回避や自己位置の推定に必要な情報である. 管中央にロボットを自動的に位置づけるスキッド車輪 [5]などの 特別な要素があるが, 車輪を能動的に操舵して移動する管内口 ボットの場合，常に管壁との衝突の危険性を有し，これに頼る だけでは障害物を避けることができない.その解決には管壁と ロボット間の位置関係を監視しつつ適切な操舵を行うことが要 求される.川口らは前後輪間の据り機構を用いて走行状態を推 
定し，管内ロボットの蛇行を回避している 6$]$. また，田口らは 接触センサで分岐方向を検出し, 管内ロボットの自動走行に役 立てている [7]，管壁面は管軸周りの回転体であり，管軸方向が 管壁の広がる向きを決める。したがって，前述の姿勢が重要で あり，本稿ではこれを走行車枠 (以下, 単に車枠と呼ぶ) の前 後方向が管軸に対して㧖れる角度と定義する。

また，オペレータにとって認識の難しい奥深い管内での遠隔 制御や自動走行において, 自己位置の認識は不可欠である。この 認識法は一般に二つに分けられる.一つはカメラ, 光センサ, 超 音波センサ，磁気センサなどの外界センサを用いて特定のマーク を観測し，環境地図と照合して同定する方法である [8] [9]. 他の 一つは加速度センサや角速度センサ，車輪に取り付けるエンコー ダなどの内界センサを用いて推定する方法である [10]〜 [12]. 後 者は車輸型ロボットにとって一般的な方法であり, 前者と比べ特 別な環境設定を必要としないメリットを有し, 二輪速度差型管 内ロボットの位置推定法としても研究されている [13]. 筆者らは すでに操舵型管内ロボットの走行軌跡の解析法を提案した [14]. その中で管内ロボットの自立を前提とするための姿勢に関する 仮定を設けているが，前述の姿勢情報を用いることによりこ うした仮定なしに管内ロボットの自己位置を推定できる。

本稿は走行環境が管壁である点を利用し自由摇動機構を用い て姿勢を検出する手法とこれを応用する管内ロボット姿勢モニ タの試作について述べる。まず，対象となる管内ロボットとこ れに取り付ける自由摇動機構の構造について説明する, 次に, 自由摇動機構から得られる回転角（以下, 摇動角と呼ぶ）を用 いて姿勢を算出する方法を明らかにする。そして，シミュレー ションにより摇動角と姿勢の関係を求め, またこの結果を利用 して機構の最適化について述べる. 最後に, 本手法の有効性を 検証するため, 管内ロボットを試作し姿勢を検出した結果につ いて報告する。

\section{2. 管内口ボットと自由摇動機構の構造}

本稿で扱うロボットは Fig. 1 のように二つの車枠とこれら を結ぶ中央軸 (以下, 腕と呼ぶ) で構成される. 文献 [4]は腕が 管軸を通るのを前提とするが，本手法では腕の位置は任意であ る、ただし，ロボットが検査装置などを装備する場合，腕が上 下車枠から独立して自由に回転することは望ましくない。した がって, Fig.2のように回転角 $\alpha$ を与える腕軸周りの回転関 節を下側車枠だけに備えることにする. 腕はパンタグラフ機構 などで構成され，上下車染を管壁方向に押しつけ，上下車枠の 推進力によって管軸方向に進む。したがって，ロボットの移動 軌跡は一般に管軸方向に伸びる。しかし, 車枠の向きは必ずし も管軸方向と一致せず，この㨭れによってロボットは管軸周り に移動し，障害物回避や U ターンを可能にする.

上下の車枠を独立ステアリング方式とし, Fig. 1，2 に示すよ うに，上側は前後にそれぞれ一つの車輪，下側はそれぞれ二つ の車輪を有する。ただし，下側の前後二輪はともに間隔をおい て同方向に操舵される. 以下，同方向に並ぶ二つの左右車輪を 二重車輪と呼ぶ [4]. 二重車輪は車枠前後方向中心軸周りに摇動 可能なフレームによって車枠本体に取り付けられ，車枠の動き に応じて管壁面をなぞるように自動的に回転する。このとき, 得

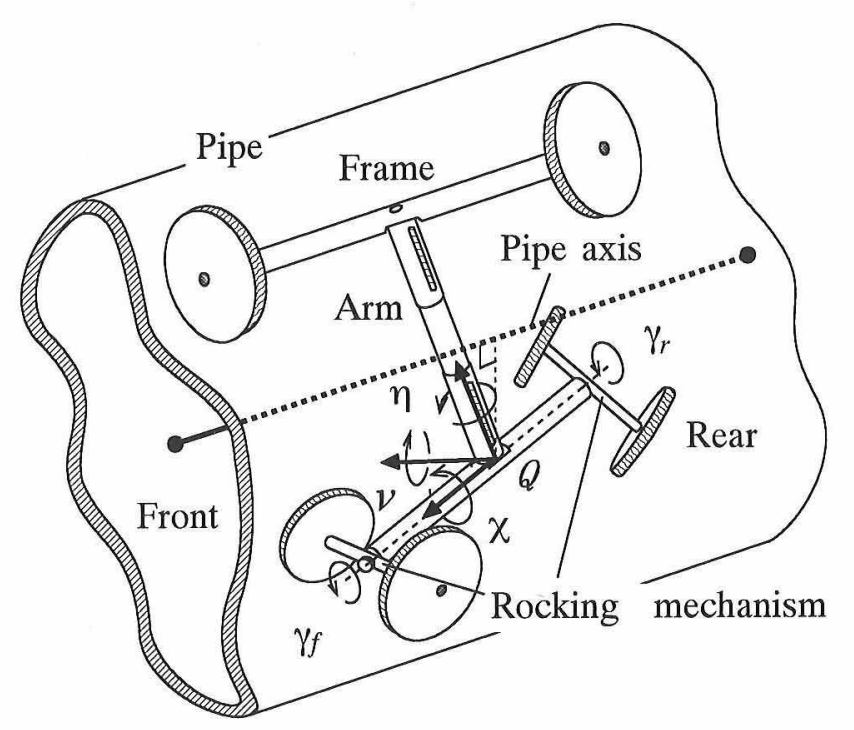

Fig. 1 Sketch of the free rocking mechanism of the wheel shaft around the main robot stem in the pipe

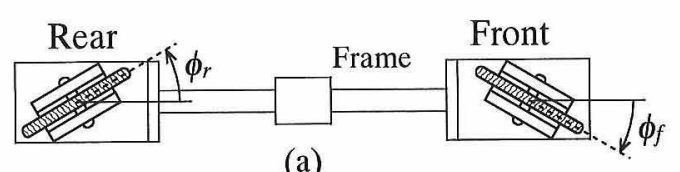

(a)

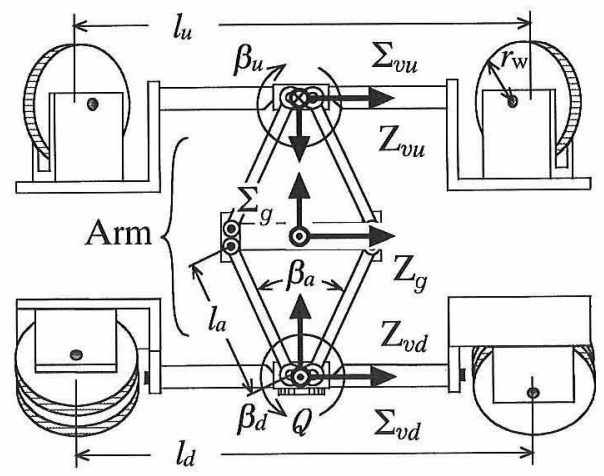

(b)

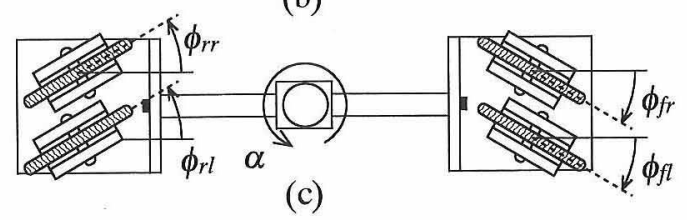

(c)

Fig. 2 The robot structure. (a), (b) and (c) are top, side and bottom views, respectively

られる摇動角 $\gamma_{f}, \gamma_{r}$ (Fig. 1 参照) を用いて下側車枠の姿勢を 算出する.ささらに, 回転角 $\alpha, \beta_{u}, \beta_{a}, \beta_{d}$ を用いて, 構造的に 定まる腕の変形状況を算出し, 下側車枠に対する上側車枠およ びロボット全体の姿勢を得る。なお， $\gamma_{f}, \gamma_{r}, \alpha, \beta_{u}, \beta_{a}, \beta_{d}$ はポテンショメータなどのセンサによって検出されるものとす る、この他，座標系に関連する記号を次のように定義する，た だし，すべて右手系とする (Fig. 2, 3 参照). 
$\Sigma_{v}$ ：車枠座標系 $\left(\mathrm{X}_{v}, \mathrm{Y}_{v}, \mathrm{Z}_{v}\right)$. 車枠中心を原点とし, その 前後方向を $\mathrm{Z}_{v}$, 腕方向と $\mathrm{Z}_{v}$ のなす平面の法線方向を $\mathrm{Y}_{v}$ とする（下側車枠中心を $Q$ )

$\Sigma_{g}$ : 管内ロボット座標系 $\left(\mathrm{X}_{g}, \mathrm{Y}_{g}, \mathrm{Z}_{g}\right)$. 腕の中心を原点と し, パンタグラフ機構の前後伸縮方向を $\mathrm{Z}_{g}$, パンタグ ラフ機構の上下伸縮方向を $\mathrm{X}_{g}$ とする

$\Sigma_{s}$ : 自由摇動機構座標系 $\left(\mathrm{X}_{s}, \mathrm{Y}_{s}, \mathrm{Z}_{s}\right)$. 二重車輪の回転中心 間の中点を原点とし，下側車枠前後方向を $\mathrm{Z}_{s}\left(\mathrm{Z}_{v d}\right.$ に 同じ)，二重車輪の回転中心を結ぶ方向を $Y_{s}$ とする

$l:$ 車枠長. 上下で同じ $\left(l_{u}=l_{d}\right)$

$l_{a}:$ パンタグラフ機構の 1 リンク長

$h:$ 二重車輪の間隔（左右の車輪間隔）

$r_{\mathrm{w}}$ : 車輪半径. 全輪で同じ

$\phi$ : 操舵角 $\left(\phi_{f}, \phi_{r}, \phi_{f l}, \phi_{f r}, \phi_{r l}, \phi_{r r}\right)$

$\alpha$ : 下側車枠に対する腕の $\mathrm{X}_{v d}$ 軸周りの回転角

$\beta$ : 上下車枠に対する腕の $\mathrm{Y}_{v}$ 軸周りの回転角. すなわち, $\mathrm{Y}_{v u}$ と $\mathrm{Y}_{v d}$ に関し，それぞれ $\beta_{u}, \beta_{d}$

$\beta_{a}:$ パンタグラフ機構の開き角

$\gamma$ : 摇動角. $\mathrm{X}_{v d}$ と $\mathrm{X}_{s}$ の交角

$u, d ：$ 車枠の上下を区別する添字

$f, r$ ：車枠の前後を区別する添字

$f l, f r$ : 下側車枠前車輪の左右を区別する添字

$r l, r r ：$ 下側車枠後車輪の左右を区別する添字

上記自由摇動機構はロボット制御において転倒を未然に防ぐ のに役立つ、例えば，ロボットは上下車枠の管軸方向への位置 ずれが大きくなると腕の押しつけ力により本来の姿勢を維持で きなくなり，また管中央から離れると車輪の滑りを起こしやす くなる. 自由摇動機構はこのような転倒に至らないようにする

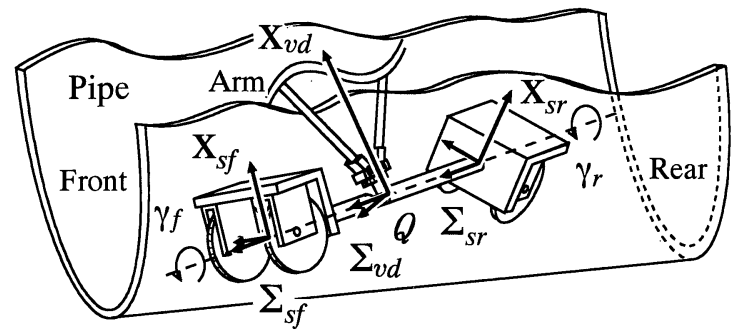

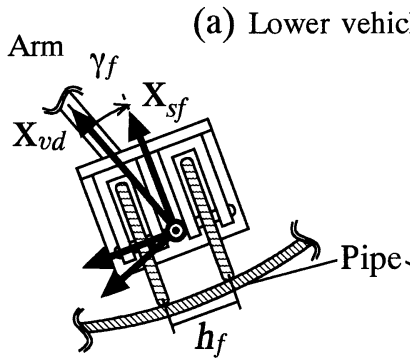

(b) $\Sigma_{s f}$

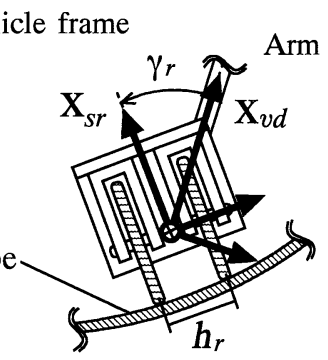

(c) $\Sigma_{s r}$
Fig. 3 The structure of the free rocking mechanism. (a) is the lower frame in pipe. (b) and (c) are front and rear views of the mechanisms, respectively
ため, ロボット自身の状態を監視し, 管軸対称な姿勢を保つ制 御の実現に有効な情報を提供する。

\section{3. 下側車枠の姿勢パラメータ}

管形状としてレデューサ，曲管などがあるが，本稿は基本形 の直管を取り扱う。これは文字通り直線状の管で，円筒面を用 いて内壁をモデル化できる. Fig. 4 はこのモデルを示す. 図中 の記号は次を意味する。

$\Sigma_{b}$ ：基準座標系 $\left(\mathrm{X}_{b}, \mathrm{Y}_{b}, \mathrm{Z}_{b}\right)$. 管入口の軸上に原点をも ち，管軸方向を $\mathrm{Z}_{b}$ とする

$r_{p}$ : 管内壁半径

$(e, \theta, z): \Sigma_{b}$ から見る下側車枠中心 $Q$ の位置. ただし, $e$ は 管内壁半径方向距離, $\theta$ は $\mathrm{X}_{b}$ を基準とする管周方 向角, $z$ は管軸方向距離とする

$\Sigma_{\xi}$ : 下側車枠に関する管軸上基準座標系 $\left(\mathrm{X}_{\xi}, \mathrm{Y}_{\xi}, \mathrm{Z}_{\xi}\right)$. 車枠中心から管軸へ垂線を下ろす点を原点, また垂 線方向を $\mathrm{X}_{\xi}$, 管軸方向を $\mathrm{Z}_{\xi}$ とする

$(\eta, \nu, \chi): \Sigma_{\xi}$ から見る下側車枠座標系 $\Sigma_{v d}$ の姿勢. ただし, $\eta, \nu, \chi$ は $\mathrm{X}_{v d}, \mathrm{Y}_{v d}, \mathrm{Z}_{v d}$ 順の各軸周りの回転角 (Fig. 1，4 参照). 以下, これらの直感的な理解を容 易にするためそれぞれを，ヨー角，ピッチ角，ロー ル角と呼ぶ

なお，局所座標系である $\Sigma_{\xi}$ は下側車枠下の管壁上の位置 $(\theta, z)$ と共に変化する。自由摇動機構を用いて求める下側車枠 の姿勢パラメータはこの座標系における $(\eta, \nu, \chi)$ の值として定 まる，管壁上の自己位置 $(\theta, z)$ が求まるとき， $\Sigma_{b}$ における下 側車枠の姿勢も定まるのは明らかである. 次章で摇動角 $\gamma_{f}, \gamma_{r}$ を用いて $(\eta, \nu, \chi)$ の值の算出法を述べる.

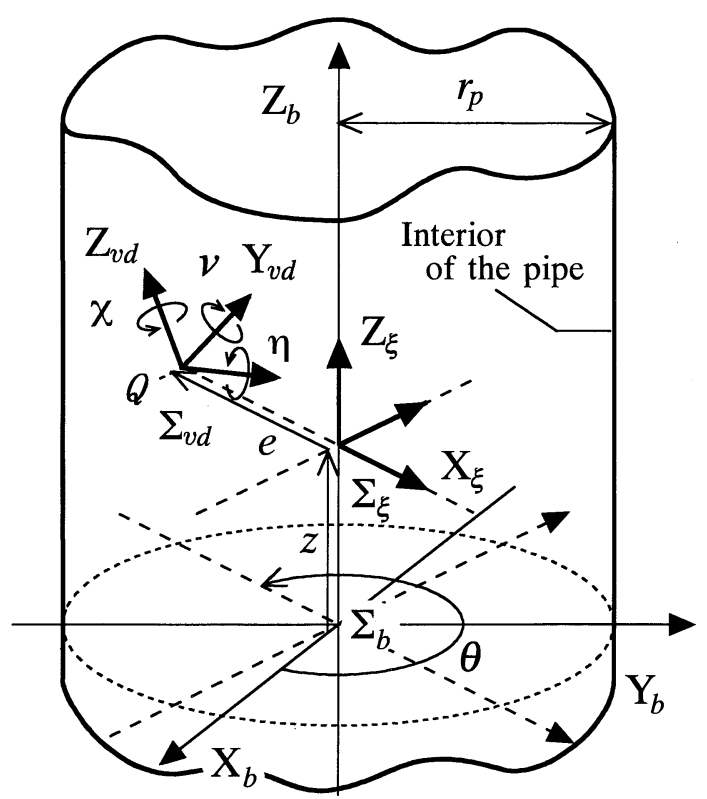

Fig. 4 Orientation of the robot in the straight pipe model 


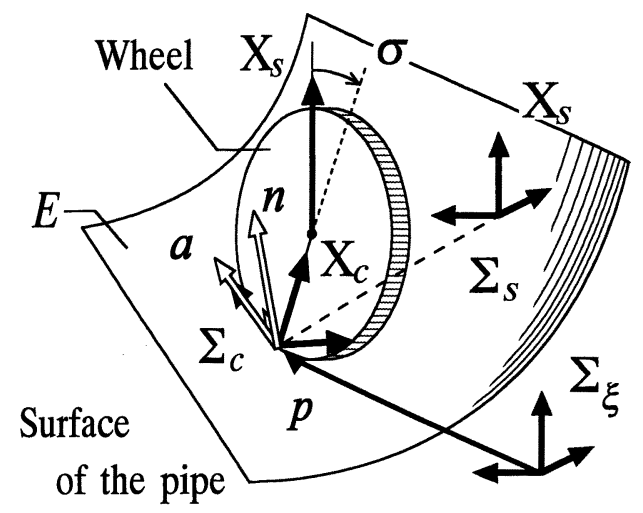

Fig. 5 Contact between the wheel and the pipe

\section{4. 姿勢の算出法}

摇動角を用いる下側車枠姿勢の算出法と腕周りの上下車枠回転 角を用いる上側車枠とロボットの姿勢の算出法について述べる。

\section{1 下側車枠の姿勢算出}

下側車枠は管壁に押しつけられることで管内姿勢を維持・変 更する。つまり，姿勢パラメータと摇動角の関係が管壁と下側 車枠間に生じる唯一の構造的拘束である接地条件から決定され る. 具体的には下側車枠に備わる 4 輪に接地点座標系 $\Sigma_{c}$ を設 定し， $\Sigma_{\xi}$ から $\Sigma_{c}$ までの同次変換行列を定義する. ただし， $\Sigma_{c}$ は接地点を原点とし, 車輪接線方向を $\mathrm{Z}_{c}$, 車軸方向を $\mathrm{Y}_{c}$ とす る座標系 $\left(\mathrm{X}_{c}, \mathrm{Y}_{c}, \mathrm{Z}_{c}\right)$ である. この同次変換行列を使って得 られる接地点は, 摇動角と求めるべき姿勢パラメータ $\eta, \nu, \chi$ および管軸から点 $Q$ までの距離 $e$ を含み, これらに管壁形状 によって定まる接地条件を適用し, 非線形連立方程式を導出す る. そして, 自由摇動機構から入力される摇動角情報を用いて この方程式を解き，姿勢パラメー夕を算出する．以下，これを 䛨説する.

接地点座標系 $\Sigma_{c}$ を Fig. 5 のように設定する。なお，車輪は 十分薄くて堅いことを想定し，厚みのない剛性円盤でモデル化 する。このため，車輪は管壁と点接触する．また，関連する記 号を次のように定義する。

${ }^{\%} \boldsymbol{T}_{\#}: \Sigma_{\%}$ から見る $\Sigma_{\#}$ の位置・姿勢を表す同次変換行列

$E$ : 管壁面

$p:$ 車輪上の接地点

$\boldsymbol{a}: \boldsymbol{p}$ における車輪の接線ベクトル

$n: p$ における管壁面の法線ベクトル

$\sigma:$ 車輪上の接地点を記述する角度変数. $\mathrm{X}_{s}$ 軸と $\mathrm{X}_{c}$ 軸 の交角

$\Sigma_{\xi}$ 加見る $\Sigma_{v d}$ の位置・姿勢を表す同次変換行列 ${ }^{\xi} \boldsymbol{T}_{v d}$ は Fig. 4 中の並進パラメー夕 $e$ と姿勢パラメー夕 $\eta, \nu, \chi$ を用 いる座標変換により,

$$
{ }^{\xi} \boldsymbol{T}_{v d}=\operatorname{Trans}(e, 0,0) \operatorname{Rot}(x, \eta) \operatorname{Rot}(y, \nu) \operatorname{Rot}(z, \chi)(1)
$$

ただし, $\operatorname{Trans}(e, 0,0), \operatorname{Rot}(x, \eta), \operatorname{Rot}(y, \nu), \operatorname{Rot}(z, \chi)$ は, それぞれ $\mathrm{X}_{\xi}$ 軸方向への並進, $\mathrm{X}_{v d}, \mathrm{Y}_{v d}, \mathrm{Z}_{v d}$ 軸周りの回転 に関する 4 行 4 列の座標変換行列である. ゆえに， $\Sigma_{\xi}$ から見
る前右輪接地点座標系 $\Sigma_{c f r}$ の位置 ·姿勢を表す同次変換行列 ${ }^{\xi} \boldsymbol{T}_{c f r}$ は,

$$
\begin{aligned}
{ }^{\xi} \boldsymbol{T}_{c f r} & ={ }^{\xi} \boldsymbol{T}_{v d}{ }^{v d} \boldsymbol{T}_{c f r} \\
& =\left(\begin{array}{llll}
x_{f r 1} & y_{f r 1} & z_{f r 1} & p_{f r 1} \\
x_{f r 2} & y_{f r 2} & z_{f r 2} & p_{f r 2} \\
x_{f r 3} & y_{f r 3} & z_{f r 3} & p_{f r 3} \\
0 & 0 & 0 & 1
\end{array}\right)
\end{aligned}
$$

ここで, 点 $\boldsymbol{p}$ が接地点であるための条件は, A. 接地点は管 壁上に存在する，B. 接地点での管壁面の法線と車輪の接線は直 交する，の二つにある。そこで, $z$ を任意として $E$ を

$$
x^{2}+y^{2}=r_{p}^{2}
$$

で表す．前右輪接地点 $\boldsymbol{p}_{f r}\left(p_{f r 1}, p_{f r 2}, p_{f r 3}\right)$ は上式を満たすの で条件 A.は,

$$
p_{f r 1}{ }^{2}+p_{f r 2}{ }^{2}=r_{p}^{2}
$$

一方，直管内壁は次の円筒面でも表される.

$$
\boldsymbol{E}(\mathrm{u}, \mathrm{v})=\left(F_{1}, F_{2}, F_{3}\right)
$$

ただし， $F_{1}, F_{2}, F_{3}$ は媒介变数 u, vを用いて，

$$
\begin{aligned}
& F_{1}=r_{p} \cos \mathrm{u} \\
& F_{2}=r_{p} \sin \mathrm{u} \\
& F_{3}=\mathrm{v}
\end{aligned}
$$

よって，直管の法線ベクトルnは，

$$
\begin{aligned}
\boldsymbol{n} & =\frac{\partial \boldsymbol{E}}{\partial \mathrm{u}} \times \frac{\partial \boldsymbol{E}}{\partial \mathrm{v}} \\
& =\left(r_{p} \cos \mathrm{u}, r_{p} \sin \mathrm{u}, 0\right) \\
& =\left(F_{1}, F_{2}, 0\right)
\end{aligned}
$$

ゆえに, $\boldsymbol{p}_{f r}$ における直管の法線ベクトル $\boldsymbol{n}_{f r}$ は次式で表せる.

$$
\boldsymbol{n}_{f r}=\left(p_{f r 1}, p_{f r 2}, 0\right)
$$

また, $\boldsymbol{p}_{f r}$ における車輪の接線べクトル $\boldsymbol{a}_{f r}$ は， $\Sigma_{c}$ の定義よ り，その $\mathrm{Z}$ 軸である $\mathrm{Z}_{c f r}$ に等しい. ゆえに, 式 $(2)$ から,

$$
\boldsymbol{a}_{f r}=\left(z_{f r 1}, z_{f r 2}, z_{f r 3}\right)
$$

式 (8), (9) より,

$$
\boldsymbol{n}_{f r} \cdot \boldsymbol{a}_{f r}=p_{f r 1} z_{f r 1}+p_{f r 2} z_{f r 2}
$$

したがって，上式に条件 B. を反映させると，

$$
p_{f r 1} z_{f r 1}+p_{f r 2} z_{f r 2}=0
$$

同様にして, 他の車輪の接地点 $\boldsymbol{p}_{f l}, \boldsymbol{p}_{r r}, \boldsymbol{p}_{r l}$ に条件 A. と B. を適用し，それぞれ次を得る。

$\boldsymbol{p}_{f l}$ について

$$
p_{f l 1}^{2}+p_{f l 2}^{2}=r_{p}^{2}
$$




$$
p_{f l 1} z_{f l 1}+p_{f l 2} z_{f l 2}=0
$$

$\boldsymbol{p}_{r r}$ について

$$
\begin{aligned}
& p_{r r 1}^{2}+p_{r r 2}^{2}=r_{p}^{2} \\
& p_{r r 1} z_{r r 1}+p_{r r 2} z_{r r 2}=0
\end{aligned}
$$

$\boldsymbol{p}_{r l}$ について

$$
\begin{aligned}
& p_{r l 1}^{2}+p_{r l 2}{ }^{2}=r_{p}^{2} \\
& p_{r l 1} z_{r l 1}+p_{r l 2} z_{r l 2}=0
\end{aligned}
$$

式 (4), (11), (12) 〜 (17) の八つの式から姿勢パラメー夕を 算出する.これらの式は $\eta, \nu, \chi, e, \gamma_{f}, \gamma_{r}, \phi_{f r}, \phi_{f l}, \phi_{r r}$, $\phi_{r l}, \sigma_{f r}, \sigma_{f l}, \sigma_{r r}, \sigma_{r l}$ の計 14 変数を含む. しかし, $\phi_{f r}$, $\phi_{f l}, \phi_{r r}, \phi_{r l}$ の 4 変数は操舵角であるため既知である. した がって, 自由摇動機構から得られる摇動角 $\gamma_{f}, \gamma_{r}$ の 2 変数を 入力することにより, 残る $\eta, \nu, \chi, e, \sigma_{f r}, \sigma_{f l}, \sigma_{r r}, \sigma_{r l}$ の 8 変数の值を, 上述の八つの式から算出できる. 結局, 姿勢パ ラメータ $\eta, \nu, \chi$ の值が得られる。このとき, $e$ も算出され ${ }^{\xi} \boldsymbol{T}_{v d}$ が定まる.

\section{2 上側車枠とロボットの姿勢算出}

腕に取り付けられるセンサの検出值 $\alpha, \beta_{u}, \beta_{a}, \beta_{d}$ が得ら れると下側車枠に対するロボットの姿勢 ${ }^{v d} \boldsymbol{T}_{g}$ とロボットに対 する上側車枠の姿勢 ${ }^{g} \boldsymbol{T}_{v u}$ が次式より求まる.

$$
\begin{aligned}
& { }^{v d} \boldsymbol{T}_{g}=\left(\begin{array}{ll}
C \beta_{d} & 0 \\
S \alpha S \beta_{d} & C \alpha \\
-C \alpha S \beta_{d} & S \alpha \\
0 & 0
\end{array}\right. \\
& \left.\begin{array}{ll}
S \beta_{d} & \left(h_{a} / 2\right) C \beta_{d} \\
-S \alpha C \beta_{d} & \left(h_{a} / 2\right) S \alpha S \beta_{d} \\
C \alpha C \beta_{d} & -\left(h_{a} / 2\right) C \alpha S \beta_{d} \\
0 & 1
\end{array}\right) \\
& { }^{g} \boldsymbol{T}_{v u}=\left(\begin{array}{llll}
-C \beta_{u} & 0 & -S \beta_{u} & h_{a} / 2 \\
0 & -1 & 0 & 0 \\
-S \beta_{u} & 0 & C \beta_{u} & 0 \\
0 & 0 & 0 & 1
\end{array}\right)
\end{aligned}
$$

ただし， $h_{a}$ はパンタグラフ機構の上下伸縮長であり，

$$
h_{a}=2 l_{a} C\left(\beta_{a} / 2\right)
$$

また， $S \theta$ と $C \theta$ はそれぞれ $\sin \theta, \cos \theta$ を表す。

したがって， $\Sigma_{\xi}$ から見るロボットと上側車枠の姿勢 $\boldsymbol{\xi}_{\boldsymbol{T}} \boldsymbol{T}_{g}$, ${ }^{\xi} \boldsymbol{T}_{v u}$ は次式より求まる.

$$
\begin{aligned}
{ }^{\xi} \boldsymbol{T}_{g} & ={ }^{\xi} \boldsymbol{T}_{v d}{ }^{v d} \boldsymbol{T}_{g} \\
{ }^{\xi} \boldsymbol{T}_{v u} & ={ }^{\xi} \boldsymbol{T}_{g}{ }^{g} \boldsymbol{T}_{v u}
\end{aligned}
$$

\section{5. 自由摇動機構最適化のためのシミュレーション}

前章の算出法を用いて姿勢検出のシミュレーションを行い, 下 側車朹の姿勢パラメータと摇動角の関係およでこの考察から得 られる自由摇動機構の最適化の指針を明らかにする。

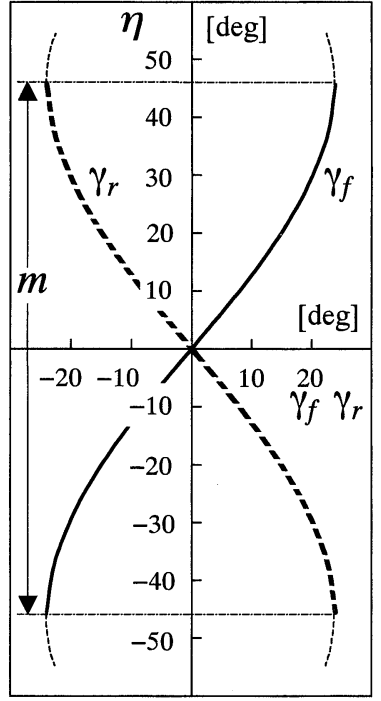

(a)

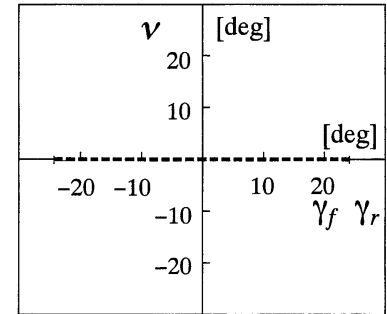

(b)

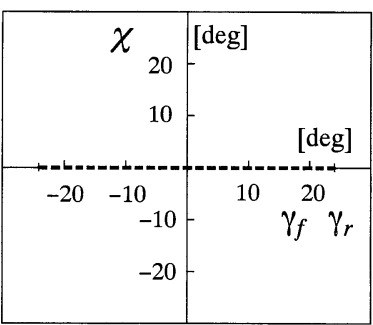

(c)
Fig. 6 Relations of the parameters $\eta, \nu$ and $\chi$ versus rocking angles $\gamma_{f}$ and $\gamma_{r}$ under the rate -1 of $\gamma_{f} / \gamma_{r}$. (a), (b) and (c) are concerned with $\eta, \nu$ and $\chi$, respectively

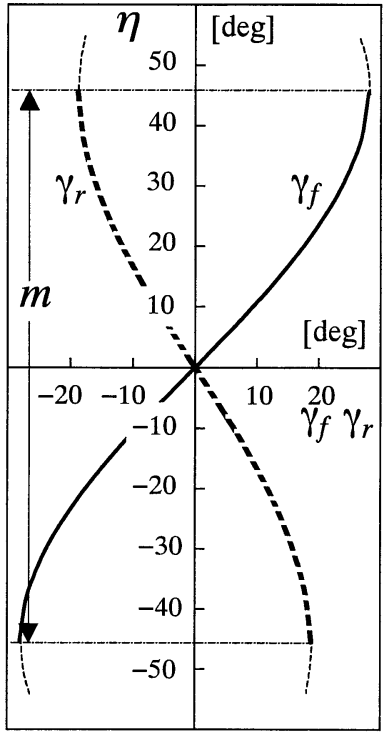

(a)

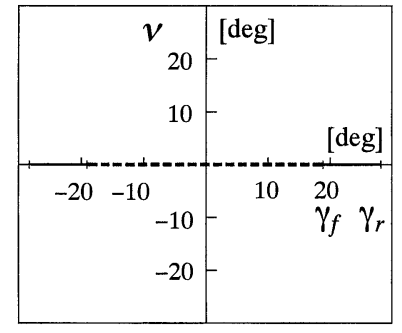

(b)

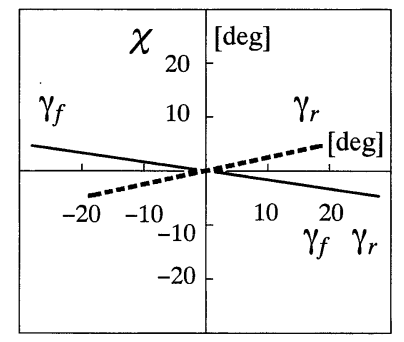

(c)
Fig. 7 Relations of the parameters $\eta, \nu$ and $\chi$ versus rocking angles $\gamma_{f}$ and $\gamma_{r}$ under the rate -1.5 of $\gamma_{f} / \gamma_{r}$. (a), (b) and (c) are concerned with $\eta, \nu$ and $\chi$, respectively

\section{1 下側車枠の姿勢パラメータと摇動角の関係}

前後摇動角 $\gamma_{f}, \gamma_{r}$ はポテンショメータなどのセンサから入 力される值で, 走行中に変化する. シミュレーションでは, こ れを仮定して自由摇動機構を管壁面に押しつける状況を模擬し， その瞬間における姿勢パラメー夕を算出する。なお，管壁およ び車枠関連のパラメータの值を次とする.

$$
\begin{array}{ll}
r_{p}=10[\mathrm{~cm}], & l_{d}=10[\mathrm{~cm}], \quad h_{f}=h_{r}=10[\mathrm{~cm}], \\
r_{\mathrm{w}}=2.5[\mathrm{~cm}], & \phi_{f r}=\phi_{f l}=\phi_{r r}=\phi_{r l}=0[\mathrm{deg}]
\end{array}
$$

$\gamma_{f} / \gamma_{r}=-1,-1.5$ のときの各パラメータの算出結果をそれぞ れ Fig. 6， 7 に示す. また, 図中の (a) および (b), (c) は $\gamma_{f}$, 


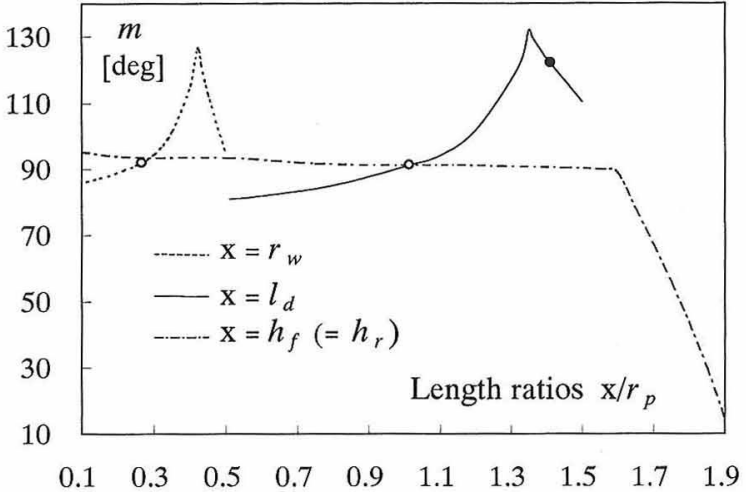

Fig. 8 Dynamic range of $m$ depending on the part's length ratios of $r_{\mathrm{w}}, l_{d}$ and $h_{f}\left(=h_{r}\right)$

$\gamma_{r}$ の変化に対する $\eta$ および $\nu, \chi$ の值をそれぞれ示す．両図 中の (a) は，ともにヨー角 $\eta$ が $\gamma$ に支配されて極大と極小の值 をとることを示す，そのため，これらの極点付近で $\eta$ の検出範 团（以下， $m$ と定義する）制限される。次に，両図中 (b) か ら，いずれもピッチ角 $\nu$ は摇動角 $\gamma$ によらず一定值 0 であり, $\gamma_{f}$ と $\gamma_{r}$ の值が重なるのを確認できる。一般に直管内における ピッチ角の変化は小さく, 前後左右対称の車枠構造の場合, 車 枠や腕の動きによらずまったく傾かないことを意味する．また， Fig. 6 (c) からロール角 $\chi$ は $\gamma_{f} / \gamma_{r}=-1$ のとき, 一定值 0 で あり，同様に $\gamma_{f}$ と $\gamma_{r}$ の值が重なるのが分かる。これは腕が 常に管軸と直交するため自明である。一方， $\gamma_{f} / \gamma_{r}=-1.5$ の 場合を示す Fig. 7 (c) から $\chi$ は摇動角に応じて線形に変化する のを確認できる．义の回転軸は自由摇動機構の軸と一致するた め, $\chi$ と $\gamma_{f}, \gamma_{r}$ は次式の関係にある.

$$
\chi=-\left(\gamma_{f}+\gamma_{r}\right) / 2
$$

したがって，実際の測定では下側車枠の停止時でも腕の動きに 応じて $\chi$ の值は変化する.

\section{2 自由摇動機構の最適化}

前節の結果から $\eta$ のが車枠構造の影響を受けることが判明 した。 $\eta$ は管内ロボットにとって管壁面に沿う進行方向に関係 し，広範囲に算出できることが望ましい。したがって，変動範 囲 $m$ を最大とする下側車枠の構成部品の組み合わせを検討する ことが自由摇動機構の最適化の内容となる. Fig. 8 に $r_{\mathrm{w}}, l_{d}$, $h_{f}\left(=h_{r}\right)$ の変化に対する $m$ の範囲を示す.ただし, 各構成部 品の大きさを個々に変化させるが，これらは走行環境を決定す る管内壁半径 $r_{p}$ で正規化され, $r_{\mathrm{w}} / r_{p}=0.25, l_{d} / r_{p}=1.00$, $h_{f} / r_{p}\left(=h_{r} / r_{p}\right)=1.00$ の場合を標準とする. 図中の白丸が これらの標準を示す. Fig. 8 から,$m$ は $r_{\mathrm{w}}, l_{d}$ とともに急に 増加し，逆に $h_{f}\left(=h_{r}\right)$ とともに徐々に減少するのを確認でき る．さらにすべての部品につき，ある時点で急激に減少するの が分かる。これは, 各構成部品の部分的な巨大化により, 車枠 の動く範囲に制限が生じることによる。

以上の結果から，前方の障害物を回避するためにも $h$ は小さ い方が有利といえる。 また， $r_{\mathrm{w}}$ の増大は $m$ を拡大するが，そ うすると車枠の重心を管壁面から離し過ぎロボットの転倒をま

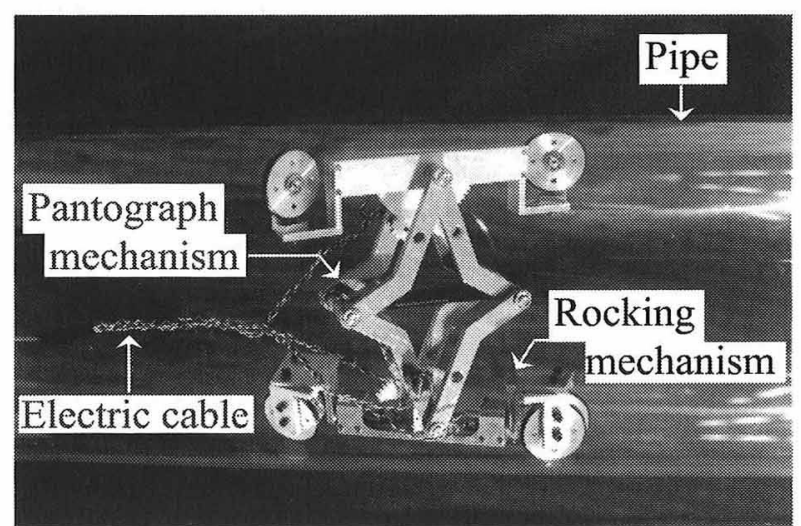

Fig.9 Overview of the robot with the free rocking mechanism

ねきやすくする。したがって， $m$ を大きくするには $r_{\mathrm{w}}$ を増や すよりも $l_{d}$ を増やす方が賢明であり，このことが自由摇動機構 の最適化の指針となる．ただし， $l_{d}$ を含む構成部品の巨大化は， 上述のように車枠の運動性を悪くする。特に管内での U ターン 時には管軸に対して車枠が直交し, 最も厳しい状態となるため, 微少な接触点の変化を考慮しない場合, $l_{d}$ に次の上限が課せら れる．図中の黒丸はこの上限を示す。

$$
l_{d} \leq 2 \sqrt{r_{p}^{2}-2 r_{\mathrm{w}} r_{p}}
$$

\section{6. ロボット姿勢モニタの試作}

摇動角から算出される姿勢パラメー夕と腕に取り付けられる センサの検出值を使い，管内ロボットの姿態を三次元表示するモ ニ夕を試作した．Fig. 9 に自由摇動機構付き車枠を含むロボッ 卜の管内外観を示す。また，その仕様を次に示す。

$$
\begin{aligned}
& l_{u}=16[\mathrm{~cm}], \quad l_{d}=16[\mathrm{~cm}], \quad l_{a}=9.4[\mathrm{~cm}], \\
& h_{f}\left(=h_{r}\right)=2[\mathrm{~cm}], \quad r_{\mathrm{w}}=2[\mathrm{~cm}]
\end{aligned}
$$

自由摇動機構抢よび腕に計 6 個のポテンショメータを取り付

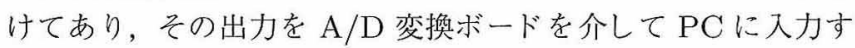
る。これらの入力データから, 下側車枠, 上側車枠, 管内ロボッ 卜全体の姿勢を算出し，これを逐次ディスプレイに表示する。こ の一例を Fig. 10 に示す。ただし，図中の（a)，(b)，(c) はそ れぞれ管外斜め上，管入口，管側面からの概観図，(d) は計算 により得られる下側車枠の姿勢パラメー夕を示す。計算時間を 含めるモニ夕の表示速度は平均毎秒 3 フレーム（計算機：NEC PC9821Ra300）である.一般に低速で移動する管内ロボットの 姿勢モニタとしては十分であると考えられる。

\section{7. と め}

車枠の前後方向軸周りに摇動自在な軸を持ち，その両端に車 輪を備える二重車輪摇動機構を管内ロボットに導入し, 摇動角 を入力して車枠执よびロボット全体の姿勢を検出する方法を提 案した。さらに, 姿勢検出のシミュレーションを行い自由摇動 機構を構成する部品の最適化について考察し, 姿勢モ二夕を備 えるロボットの設計に有益な指針を明らかにしたままたこう した指針を反映させる自由摇動機構を備えるロボットを試作し， 


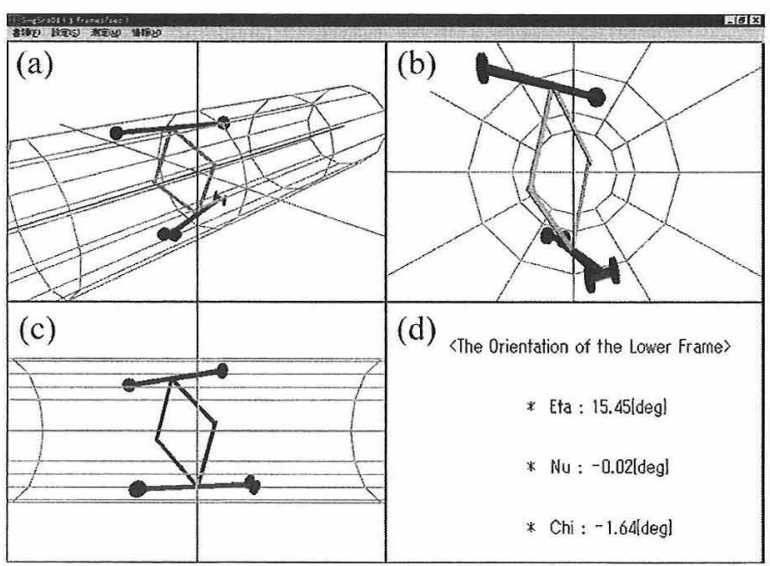

Fig. 10 Display of the robot's orientations. (a), (b) and (c) are bird's-eye, front and side views, respectively. (d) is calculated results of the lower frame's orientation

提案するモニタ法の有効性を確認した。

今後，姿勢モ二夕を装備する管内ロボットの転倒回避や曲面 上での位置推定などの課題に取り組んでいく予定である.

\section{参 考 文 献}

[1] 青野, 藤井, 初本, 神谷： “起伏地に扔ける移動機の位置計測”, 日本 ロボット学会誌, vol.16, no.5, pp.728-733, 1998.

[2] 岡田, 木村, 三村：“フロート型平衡覚センサの基碟的検討”, 日本
ロボット学会誌, vol.17, no.4, pp.587-594, 1999.

[3] Y.F. Zheng and J.Shen: "Gait synthesis for the SD-2 biped robot to climb sloping surface," IEEE Trans. on Robotics and Automation, vol.6, no.1, pp.86-96, 1990.

[4] 岡田, 大谷, 吉田：“管内走行車の姿勢検出の一方法 (二重車輪によ る自由回転摇動機構の利用)", 第 15 回日本ロボット学会学術講演会 予稿集, pp.253-254, 1997.

[5] 岡田, 大谷, 川崎, 藤原, 三村: “管内走行スキッド車輪の構造とその 移動特性”, 日本ロボット学会誌, vol.17, no.6, pp.905-913, 1999.

[ 6 ] 川口, 吉田, 嚴, 菊田: “磁石車輪型管内走行ロボットの走行制御”, 第 13 回日本ロボット学会学術講演会予稿集, pp.881-882, 1995.

[ 7 ] 田口, 河原崎：“ユニット型小口径配管内走行検査ロボットの開発”, 日本ロボット学会誌, vol.15, no.2, pp.230-235, 1997.

[8] 小森谷, 舘, 谷江: “移動ロボットの自律誘導の一方法”, 日本ロボッ 卜学会誌, vol.2, no.3, pp.222-231, 1984.

[9] 津村, 藤原, 橋本, 唐：“レーザ灯台を用いた移動体の位置・方位測 定法”, 日本ロボット学会誌, vol.2, no.6, pp.557-565, 1984.

[10] 津村, 藤原, 白川, 岡崎: “移動体の現在位置・進行方位の計測の一方 法”, 日本機械学会論文集, vol.C47, no.421, pp.1153-1160, 1980.

[11] 小森谷, 大山：“光ファイバージャイロを利用した移動ロボットの位 置推定の一手法”, 日本ロボット学会誌, vol.14, no.4, pp.532-537, 1996.

[12] 前山, 大矢, 油田： “移動ロボットの屋外ナビゲーションのためのオド メトリとジヤイロのセンサ融合によるデッドレコニング・システム”, 日本ロボット学会誌, vol.15, no.8, pp.1180-1187, 1997.

[13] K.R. Kim, J.C. Lee and J.H. Kim: "Dead-reckoning for a Twowheeled Mobile Robot on Curved Surfaces," Proc. of IEEE Int. Conf. on Robotics and Automation, pp.1732-1737, 1996.

[14] 大谷, 岡田, 吉田: “車輪型ロボットの直管内走行軌跡の解析”, 日本 ロボット学会誌, vol.18, no.3, pp.453-461, 2000.

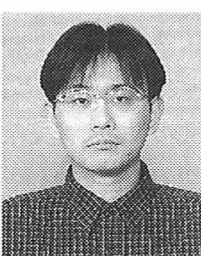

大谷智康 (Tomoyasu Ohya)

1971 年 7 月 7 日生. 1995 年新潟大学工学部情報工 学科卒業. 1997 年同大学大学院自然科学研究科情 報・計算機工学専攻博士前期課程修了. 同年, 同大 学大学院自然科学研究科情報理工学専攻博士後期課 程進学, 現在に至る。（日本ロボット学会学生会員）

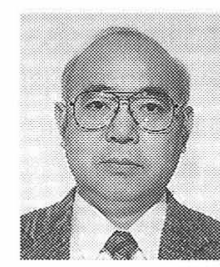

\section{岡田徳次 (Tokuji Okada)}

1947 年 3 月 5 日生. 1969 年新潟大学工学部電気 工学科卒業. 同年, 現電子技術総合研究所に入所. 知能ロボットシステムの研究に従事. 1987 年 7 月 新潟大学工学部. 現在福祉人間工学科教授. 工学博 士.ロボティクス, インテリジェントセンサなどの 研究に従事. 計測自動制御学会, 日本機械学会, 電 子情報通信学会, IEEE などの会員. （日本ロボット学会正会員）

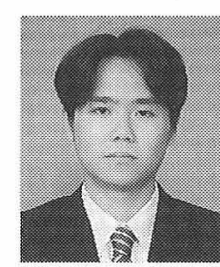

吉田 亮 (Ryo Yoshida)

1975 年 6 月 4 日生. 1998 年新潟大学工学部情報 工学科卒業. 2000 年同大学大学院自然科学研究科 情報・計算機工学専攻博士前期課程修了, 同年アル パイン (株)に入社. 